\title{
A Review on Cultivation and Pharmacological Potential of White Button Mushroom (Agaricus bisporus)
}

\author{
E. Keshamma ${ }^{1}$, M. S. Krishnaprasad ${ }^{2}$, B. T. Sridhar ${ }^{3}$, T. J. Nalini ${ }^{4}$, \\ R. Geethanjali ${ }^{4}$, K. N. Shivakumara ${ }^{3}$ and U. B. Roy $^{5}$ \\ ${ }^{1}$ Department of Biochemistry, Maharani Cluster University, Palace Road, Bengaluru, \\ Karnataka, India \\ ${ }^{2}$ Department of Health and Family Welfare, District Hospital, Chikkaballapura, \\ Karnataka, India \\ ${ }^{3}$ Department of Chemistry, \\ ${ }^{4}$ Department of Botany, Maharani Cluster University, Palace Road, Bengaluru, \\ Karnataka, India \\ ${ }^{5}$ Department of Zoology and Genetics, Government Science College, Bengaluru, \\ Karnataka, India \\ *Corresponding author
}

\section{A B S T R A C T}

\section{Keywords}

Agaricusbisporus, white button mushroom, Cultivation, Pharmacology, Breeding

\section{Article Info}

Accepted: 12 April 2021 Available Online: 10 May 2021
Nature has been a source of medicinal agents for thousands of years and an impressive number of modern drugs have been isolated from natural sources, based on their use in traditional medicine. Since ancient time's plants as well as fungus sources of medicinal compounds have continued to play a dominant role in maintenance of human health. Over $50 \%$ of all modern clinical drugs are of natural product origin and play an important role in drug development programs in the pharmaceutical industry. Mushrooms are highly nutritious and environment friendly crops that carry numerous medicinal benefits. The cultivation of edible mushrooms carries great relevance in todays' world in the context of a growing population and extreme pressure on the environment. White button mushroom (Agaricus bisporus) is a very important nutritional and medicinal species which is used for recycling agro wastes including wheat straw, reed plant wastes, waste paper, oat straw, waste tea leaves, some water plants and others. The standardized cultivation techniques to be followed for cultivation laboratory scale button mushroom are as follows (i). compost to be prepared by short method of composting (ii). Cultivation trials of $A$. bisporus to be carried out in a closed room provided with air conditioner as source of cooling (iii). The relative humidity inside the cropping rooms to be maintained to $60-70 \%$ (iv). Spawn run will be completed in 15 days and required 12-15 days more for case run. These findings revealed that button mushroom can possibly be cultivated under laboratory condition. This can be a means of livelihood and a source of economic empowerment for women in both urban and rural areas and for small holder farmers, apart from being a source of food production. However, there is resurgence to propel efforts in terms of improvement of tools available to the breeder, decoding mushroom genome for new strain development in the future for the welfare of commercial pressure facing industry. 


\section{Introduction}

The world population is increasing day by day. Currently, it is considered nearly 7 billion. Some theories suggest that by the year 2050, the global population will reach to 9 billion, and during 2100, it could be 20 billion (Bacci, 2012). Lack of food and deterioration in human health will be burning issue due to the population growth and urbanization with a concomitant reduction in arable land. To address global food demand (especially protein) can be converted into lingo-cellulosic agricultural and forest residues into proteinrich mushrooms is one of the most economically viable and sustainable biotechnology processes (Hawksworth, 1991).

Agriculture has remained the major force of Indian economy but a fight is still on to meet the ever increasing demand of nutritional security following secondary agricultural vocation. To meet such challenges, diversification in the agricultural activities which include mushroom production is important to address the problems of quality food, health and environmental sustainability (Singh et al., 2017). In the present diet conscious era, mushrooms are increasingly considered as a future vegetable and their consumer demand has markedly expanded in the recent years owing to its medicinal and nutritional properties. Mushrooms are considered as a potential substitute of muscle protein on account of their high digestibility (Kalac, 2009). In addition to protein, mushroom is an excellent source of Vitamin$\mathrm{D}$, minerals such as potassium, iron, copper, zinc and manganese, low in calories, fat free, cholesterol free, gluten free and very low in sodium (Sharma et al., 2017). From 20102017, the mushroom industry in India has registered an average growth rate of $4.3 \%$ per annum. Out of the total mushroom produced, white button mushroom share is $73 \%$ followed by oyster mushroom (16\%), paddy straw mushroom (7\%) and milky mushroom (3\%) (Sharma et al., 2017).

The white button mushroom (Agaricus bisporus) is very popular throughout the world and is the most important mushroom of commercial significance in India (Maheshwari, 2013). It belongs to phylum Basidiomycota, class Agaricomycetes, order Agaricales and family Agaricaceae. Initially, white button mushroom production was confined to temperate hilly regions of India. However, with the development of short method of composting and optimization of fruiting conditions using the chilling system, there has been a remarkable change in its production scenario and spread to all the corners of the country. A. bisporus Imbach is the wildest and cultivated edible mushroom and represents more than $40 \%$ of the world bearing of mushrooms(Callac et al., 2000; Carlucci, 2003). It is cultivated in over 70 countries and on every ascetic, except Antarctica. The global production in the 1990s was more than $\$ 800$ million/year and increased to $\$ 12,250$ in 2002 (UN 2010) (Andersson and Gry, 2004). A. bisporus has a luscious taste with more nutritional value has very good aroma or flavoring taste is used as food and in food industries (Misharina et al., 2010).

A.bisporus is considered to have high biological activity, low toxicity and has significance folklore and ethnopharmacological significance. Apart from food and food beverages it has a role in perfumery, cosmetic industries and pharmaceutical industries (Caglarirmak, 2009; Dastager, 2009). Wild A. bisporus were referred for customer due to their flavor and texture (Sadiq et al., 2008)It has been reported lots of primary and secondary metabolites responsible for the therapeutic activity for the prevention and treatment of many diseases such as cancer, hyperlipidemia, microbial 
diseases, cardiovascular problems, liver diseases, and immune problems. A. bisporus is a litter degrading basidiomycete commonly found in humic rich environments which are useful as a model organism and cultivated in large scale for the food industry. Due to its ecological niche, it produces a variety of enzymes for detoxification and degradation of humified plant litter (Gonaus et al., 2016).

It was understood from the literature survey that medicinal agents for thousands of years and an impressive number of modern drugs have been isolated from natural sources, based on their use in traditional medicine. Since ancient time's plants as well as fungus sources of medicinal compounds have continued to play a dominant role in maintenance of human health. Over $50 \%$ of all modern clinical drugs are of natural product origin and play an important role in drug development programs in the pharmaceutical industry. Mushrooms are an important natural source of food and medicine. Traditional aboriginals knew the importance of edible and wild mushrooms and these are now being screened for their bioactivity in various ailments. However, there is scanty of information on cultivation techniques of button mushroom under laboratory conditions and recent updates on pharmacological potential button mushroom. Hence, in this narrative review of literature we aimed to describe the standardized laboratory cultivation techniques of button mushroom as climate in certain places across the globe does not permit for natural button mushroom production. Also recent perceptive on pharmacological potential of button mushroom was narrated based on recently published data and other available resources.

\section{History and Ethnopharmacological Perspectives}

A. bisporus is an edible basidiomycete mushroom native to grasslands in Europe and
North America. Commonly known as white button mushroom, is widely cultivated in most countries and it constitutes the bulk of all mushrooms consumed in the United States and Australia. Historical evidence indicates that it was first cultivated in France and that cultivar strains originated in Western Europe (Atkins, 1974; Kerrigan, 1995; Jeong et al., 2012). Ancient Egyptians believed mushrooms could grant immortality and thus, only the pharaohs were deemed worthy of eating or even touching them. In ancient Rome, mushrooms were often referred to as "food for the gods." In Russia, China, Mexico and other world cultures, folklore held that mushrooms conferred superhuman strength (Varo et al., 1980). Conventionally, the fungus was used in the treatment of cancer, cerebral stroke and heart diseases. Furthermore, it has anti-aging property. They represent as one of the world's greatest untapped resources of nutrition and palatable food of the future. Mushrooms have been found to be more effective against cancer, cholesterol reduction, stress, insomnia, asthma, allergies and diabetes. They can be used to bridge the protein malnutrition gap because they have a high amount of protein. Mushrooms are useful to increase the immunity. Hence, it provides a nutrient supplement as a form of tablets. They are also useful for diabetic and patients with cardiovascular disorders (because they contain low starch and low cholesterol). One-third of the iron in the mushrooms is available in free form. Their polysaccharide content is used as an anticancer drug and combat HIV effectively (Prasad et al., 2015; Bahl, 1983).

Biologically active compounds from the mushrooms possess antifungal, antibacterial, antioxidant, antiviral properties and have been used as insecticides and nematicides as well. There have been studies that demonstrate that women who eat these button mushrooms daily have reduced chances of getting breast cancer. The mushrooms can be thought to inhibit the 
production of enzymes that affect the production of estrogen which is a hormone that causes cancer to develop. The special effects of this substance on other kinds of cancer are still being studied (King, 1993).

\section{Various Composts for Cultivation of $A$. bisporus}

Mushrooms are considered to be heterotrophic (saprophytic) organisms and thus possess no chlorophylls, but decompose organic materials to feed off (Miles et al., 2004). A. bisporus can be cultivated on various lignocellulosic materials. Growing and cultivation of this species has succeeded on different composted organic such as chicken, horse or pigeon manures, straw residues from wheat, oat, Tifton (Andrade et al., 2008)and reed crops (Alkaisi et al., 2016; Rehman et al., 2016), corn cob (Miles et al., 2004), molasses, wheat bran (Peker et al., 2007; Baysal et al., 2007), sugarcane bagasse, tea leaves (Simsek et al., 2008), brachiaria (Brachiaria sp.) (Andrade et al., 2013), reed plant (Phragmites australis) straw (Muslat et al., 2011), water hyacinth (Eichhornia crassipes) (Reddy et al., 2013). Various compost materials used in different countries for the cultivation of button mushroom was enlisted in Table 1A, 1B and $1 \mathrm{C}$.

Also, new techniques like the new Garbage Automatic Decompose-Extinguisher (GADE) were used to produce composts for cultivating and producing $A$. bisporus and Pleurotus ostreatus with the highest growth and rate of spinning (Horisawa et al., 2006). A. bisporus has a significant role in producing lignin degradation enzymes (manganese peroxidase and laccase) (Bonnen et al., 1994) and is a ready source of enzymes, including laccase which is important in polyphenol oxidation (Hou et al., 2004). Recent work showed this enzyme was secreted by partnering $A$. bisporus and Trichoderma sp. to increase the production of this enzyme in agricultural composts (Flores et al., 2009). Spent mushroom composts have been found to be useful in organic agriculture (Beyer, 2003). The temperature inside the pile rises to $60^{\circ} \mathrm{C}$ whereas the degrees from $40-50^{\circ} \mathrm{C}$ are suitable for decomposition (Owaid, 2009).

\section{Standardised Lab Cultivation Techniques of $A$. bisporus}

\section{Spawn production}

Wheat grains should be used as support media for spawn production. Wheat grains should be boiled in water for $30 \mathrm{~min}$ (wheat grains:water; $1: 2 \mathrm{w} / \mathrm{v}$ ) so as to cook them soft enough to be pressed within the fingers. Extra water should be sieved out, grains should be allowed to cool and then mixed with calcium carbonate \& calcium sulphate powder at $10 \mathrm{~g} / \mathrm{kg}$ of wheat grains respectively. Empty glucose bottles should be filled with these grains at $250 \mathrm{~g}$ per bottle, plugged with nonabsorbent cotton, wrapped with paper and then autoclaved at 15 psi for $30 \mathrm{~min}$. After cooling the autoclaved bottles overnight, these should be shaken to restore transparent visibility of the glass and then inoculated aseptically with mycelial bits from the slant cultures. The bits should be placed in such a manner that their mycelium touched the grains. These bottles should be incubated at $22 \pm 1^{\circ} \mathrm{C}$ for 15-20 days. The culture bottles thus produced should be the master/mother cultures. After 10 days, master/mother culture should be shaken so that grains were transferred into 10-15 freshly prepared bottles. These spawn bottles should be stored at $25^{\circ} \mathrm{C}$ to use for spawning the substrate (Figure 1) (Netam et al., 2018).

\section{Composting}

Fresh, good quality wheat straw should be spread on pucca floor and wetted thoroughly for 48 hours while keeping it in the form of 
loose heap ( $\sim 0.5 \mathrm{~m}$ high) to attain $70-75 \%$ moisture content. Considering stacking day as 0 day, first turning should be done 3 days after stacking, urea at $1.8 \mathrm{~kg} / \mathrm{qt}$. of straw should be mixed with wet straw, again stacked into heap and covered with polythene and kept overnight to facilitate solubilization of the chemical fertilizer and their adsorption on to the bran. Subsequent turning should be done at 3 days' interval with a total of seven turns required for complete decomposition of compost. Wheat bran (choker) at $2.5 \mathrm{~kg}$ per quintal of straw should be mixed during $3^{\text {rd }}$ turning, while gypsum was mixed during $6^{\text {th }}$ turning at $3.5 \mathrm{~kg} / \mathrm{qt}$. of straw. Light brown colored compost having no smell of ammonia should be allowed to cool down before spawning (Figure 2) (Netam et al., 2018).

\section{Filling and spawning}

Good quality compost should be mixed with A. bisporus spawn at $0.7-1.0 \%$ of wet compost weight and filled into polythene bags of size $18 \times 20^{\prime \prime}$. The spawned compost should be then compressed, levelled and mouth of polythene bags should be covered with a clean newspaper. Compost filled bags should be then shifted to the growing room until complete mycelia impregnation. Holes should be made throughout the bag to allow aeration.

The filled bags should be incubated at 21$23^{\circ} \mathrm{C}$ with sufficient light $\&$ humidity and water should be sprayed on top of the bags covered with newspaper twice a day throughout spawn running period (Figure 3) (Netam et al., 2018).

\section{Casing}

Casing mixture should be prepared by mixing cocopeat, soil and sand $(3: 2: 1 \mathrm{v} / \mathrm{v})$. Coco-peat instead of farmyard manure should be used because of its unique water holding and structural properties, coco-peat has been regarded as the most suitable and more ideal for casing (Kaur and Rampal, 2017). All the ingredients should be separately sterilized for 30 minutes at $121^{\circ} \mathrm{C}$ at 15 psi before mixing. The sterilized casing mixture should be used to cover spawn impregnated compost bags at uniform thickness of 3-4 $\mathrm{cm}$ following removal of newspaper. Case run should be considered complete when mycelia covered the top of casing layer. Case run should be done at a temperature of $21-23^{\circ} \mathrm{C}$. Spraying of water should be continued directly on cased bags till the end of cropping (Figure 4) (Netam et al., 2018).

\section{Crop Management and Harvesting}

An air conditioner room of $10 \times 12$ sq. $\mathrm{ft}$. should be used for cultivation. Very little or no ventilation should be provided until the appearance of first pin heads. Thereafter intermittent cross-ventilation should be given for period of total 3-4 hrs per day. A temperature of $21-23^{\circ} \mathrm{C}$ should be maintained during spawn run period and $15-20^{\circ} \mathrm{C}$ after pin head stage. Relative humidity of 70$80 \%$ should be maintained throughout the cultivation.

Mushrooms should be harvested by gentle twisting and the soil end parts of fruit bodies were cut off. The yield data should be recorded daily for number of fruit bodies and their weight was observed. Spray of water should also be continued on cased bags till end of crop. Yield data for total number and total weight of fruiting bodies per bag should be recorded up to a period of 4 weeks following appearance of pin head and biological efficiency could be calculated as follows (Netam et al., 2018).

Biological efficiency $=($ Total weight of fresh mushroom/Total dry weight of compost) $\mathrm{X}$ 100 


\section{Mushroom Breeding Strategies}

Mushrooms have gained the reputation of being difficult organisms to work with and it was widely acknowledged that the mushroom, particularly A. bisporus is not easy to manipulate through breeding. During early attempts at genetic improvement in the cultivated mushroom A. bisporus, there was not much understanding of the natural breeding system. The mushroom is now known to be a "secondarily homothallic" species with a single multiallelic mating type factor (Elliott and Langton, 1981). This understanding can evaluate the breeding methods previously used and to suggest alternatives. Strain selection based on single spores, multispores or tissue culture may give improvement in the short term but is not as effective as methods with controlled crossing. Mixing fertile strains may produce hybrids but they are sometimes difficult to identify. It is better to use non-fertile isolates because only the hybrids show fruiting. Early recognition of hybrids can be done using markers that can be expressed only in hybrid cultures and the incorporation of genetic resistant trait is especially useful for this.

Increasing the yield and quality of crops as well as resistance to diseases are the primary goals for mushroom breeders and mushroom research. Other goals include reducing production costs and the efficient use of compost for growth. Methods of mass selection based on natural chance mutation and programmed mutation by ionizing radiations such as $\gamma$-rays, $\mathrm{X}$-rays and chemicals as well as cross breeding and transgenic breeding are some of the methods carried out for this purpose. However, cross and transgenic breeding are more effective and have shown greater promise and progress in the last few decades (Fan et al., 2006). Areas of research for mushroom breeding relate directly to commercial benefits such as problems associated with cultivation, distribution and storage, senescence-induced browning and disease resistance.

\section{Hybrid Breeding}

The hybrid mushroom strains introduced in the 1980s were well received and popular and have limited the choice of production characteristics and range of tolerance to environmental and cultural stresses. Cross breeding has been carried out since1983 in mushrooms with the production of hybrids in Lentinula (Zhang and Molina, 1995), Pleurotus and Agaricus (Fristche, 1983). Hybrid strains have not only given mushrooms thatshow resistance to diseases and pests but also reduced the dependence and risks of environmental and cultural stresses. Hybrids obtained by pairing monosporic cultures are cultivated to evaluate the production characteristics accompanied by RAPD and RFLP analysis. Mushroom breeding requires a large investment of capital and patience from both the breeder and grower. A number of specific industry standards have been adopted to grow strains available to the public for the last 30years. For a new strain to be successful, some modifications in growing parameters are required for optimal growth. Traditionally growers had to adapt growing systems to accommodate cultural needs such as modifying flushing regimes, watering patterns and harvesting practices to optimize strain performance. Modifying cultural practices such as frequency and timing of irrigations are required for successful future strain development.

\section{Transgenic Breeding}

At present there are no transgenic mushroom strains available commercially but several research groups are working towards that direction with good progress. The use of recombinant DNA technique for creating 
transgenic mushrooms has created numerous possibilities and opportunities. Importing genes from unrelated sources is now possible and it is not restricted to searching for desirable genes only within the species. Transformation techniques used with other filamentous fungiare being adapted for the mushroom (Van De Rhee et al., 1996a). Various techniques such as polyethylene glycol, electroporation and particle bombardment have been used to incorporate DNA into protoplasts, mycelium orbasidiospores (Li et al., 2006). An efficient homologous site-directed integration of the transformation plasmid was done by isolating the tyrosinasegenes responsible for mushroom browning from Agaricus bisporus and introducing it in antisense orientation (van de Rhee et al., 1996b). However, the multinuclear nature of fertile Agaricus mycelia presented a problem for stable transgenic mushrooms. Another gene isolated and identified in mushrooms was the mannitol-dehydrogenase (MtDH) gene and its 3-dimensional structure has now become available Sassoon et al., 2001). Isolation of this gene can allow the production of mushrooms with altered mannitol profiles and ultimately yield strains with higher dry matter content or better pathogen resistance (Stoop and Mooibroek, 1998). The use of direct gene delivery techniques such as particle bombardment has also been carried out as an alternative method for genetic transformation in mushrooms ( $\mathrm{Li}$ and Horgen, 1993). This process involves the bombardment of intact tissues with tungsten or gold particles coated with donor DNA and penetrating the recipient tissue. It has the advantage of being less laborious and often the problematic production and regeneration of protoplasts can be avoided. In many laboratories, attempts have been under taken to introduce
hygromycin-B resistance and other selectable markers by particle bombardment. However, this technique has not yet resulted in the selection of stable transformants or an applicable system.

\section{Pharmacological Activities}

\section{Anticancer activity}

A. bisporus is effective in case of breast cancer because it decreases aromatase enzyme activity and estrogen biosynthesis. The researcher evaluated the activity of mushroom extracts in the estrogen receptor positive/aromatase positive and found to have decreased testosterone induced cell proliferationin $\mathrm{MCF}-7$ aro cells but had no effect on MCF-10A, anontumorigenic cell line (Chen et al., 2006).

\section{Anticholesterolemic and antiglycemic}

Jeong et al., conducted a research investigation with the main objective to evaluate the hypothesis that intake of the fruiting bodies of $A$. bisporus regulates antiglycemic responses. For these studies the rats were fed hypercholesterolemic diet and type 2 diabetes induced by injection of streptozotocin for 3 weeks in rats. The result allowed reduced plasma glucose, TG concentrations, liver enzyme activities, alanine aminotransferase and aspartateamino transferase (Jeong et al., 2010).In hypercholesterolemic rats, oral feeding of $A$. bisporus for 4 weeks resulted in a significant decreasein plasma TC, LDL, and concluded that A.bisporus had both hypoglycemic and hypolipidemic activity in rats (Jeong et al., 2010). 
Table.1A List of compost material used across globe

\begin{tabular}{|c|c|}
\hline Component & $\begin{array}{c}\text { Proportion of Dry Matter }(\mathbf{K g}) \\
\text { Manure Compost in USA (Miles et al., 2004) }\end{array}$ \\
\hline Horse Manure & 50.00 \\
\hline Chicken Manure & 6.00 \\
\hline Beer Residues & 2.50 \\
\hline Gypsum & 1.25 \\
\hline Total weights & 59.75 \\
\hline Modified Straw Compost in Taiwan (Miles et al., 2004) \\
\hline Paddy Straw & 85.00 \\
\hline Urea & 1.00 \\
\hline Ammonium sulfate & 2.00 \\
\hline Super phosphate calcium & 3.00 \\
\hline Potassium sulfate & 0.80 \\
\hline Calcium carbonate & 2.50 \\
\hline Total weight & 94.30 \\
\hline Tea Leaf Compost in Turkey (Simsek et al., 2008$)$ \\
\hline Tea leaves & 400.00 \\
\hline Wheat bran & 113.00 \\
\hline Ammonium nitrate & 3.67 \\
\hline Urea & 2.17 \\
\hline Molasses & 16.00 \\
\hline Gypsum & 24.00 \\
\hline Total weight & 559.80 \\
\hline
\end{tabular}

Table.1B List of compost material used in Iraq

(Owaid, 2009; Muslat et al., 2014; Owaid and Ibrageem, 2017)

\begin{tabular}{|c|c|c|c|}
\hline Component & $\begin{array}{c}\text { Proportion of } \\
\text { Dry Matter }(\mathbf{K g})\end{array}$ & $\begin{array}{c}\text { Proportion of } \\
\text { Dry Matter } \mathbf{( K g})\end{array}$ & $\begin{array}{c}\text { Proportion of } \\
\text { Dry Matter } \mathbf{( K g})\end{array}$ \\
\hline Wheat straw & 400.00 & 400.00 & 400.00 \\
\hline Wheat bran & 113.00 & 113.00 & 113.00 \\
\hline Ammonium nitrate & 17.10 & 20.00 & 15.00 \\
\hline Urea & 10.10 & 12.00 & 10.00 \\
\hline Molasses & 16.00 & 16.00 & 16.00 \\
\hline Gypsum & 24.00 & 24.00 & 24.00 \\
\hline Total weight & 580.20 & 585.00 & 578.00 \\
\hline
\end{tabular}


Table.1C List of compost material used in Turkey (Baysal et al., 2007; Colak et al., 2007)

\begin{tabular}{|c|c|c|c|}
\hline $\begin{array}{c}\text { Dry Matter } \\
\text { Component }(\mathbf{K g})\end{array}$ & $\begin{array}{c}\text { Wheat Straw } \\
\text { Compost }\end{array}$ & $\begin{array}{c}\text { Reed Straw } \\
\text { Compost }\end{array}$ & $\begin{array}{c}\text { Mixture Compost } \\
(\mathbf{1 : 1 )}\end{array}$ \\
\hline $\begin{array}{c}\text { Wheat straw } \\
\begin{array}{c}\text { Phragmites australis } \\
\text { Reed straw }\end{array}\end{array}$ & 11.32 & - & 5.66 \\
\hline Chicken manure & - & 11.38 & 5.69 \\
\hline Urea & 9.33 & 9.33 & 9.33 \\
\hline Gypsum & 1.44 & 0.56 & 0.56 \\
\hline Total weight & 22.65 & 1.44 & 1.44 \\
\hline C:N ratio & $9.50: 1$ & 22.71 & 22.68 \\
\hline
\end{tabular}

Fig.1 Preparation of spawn

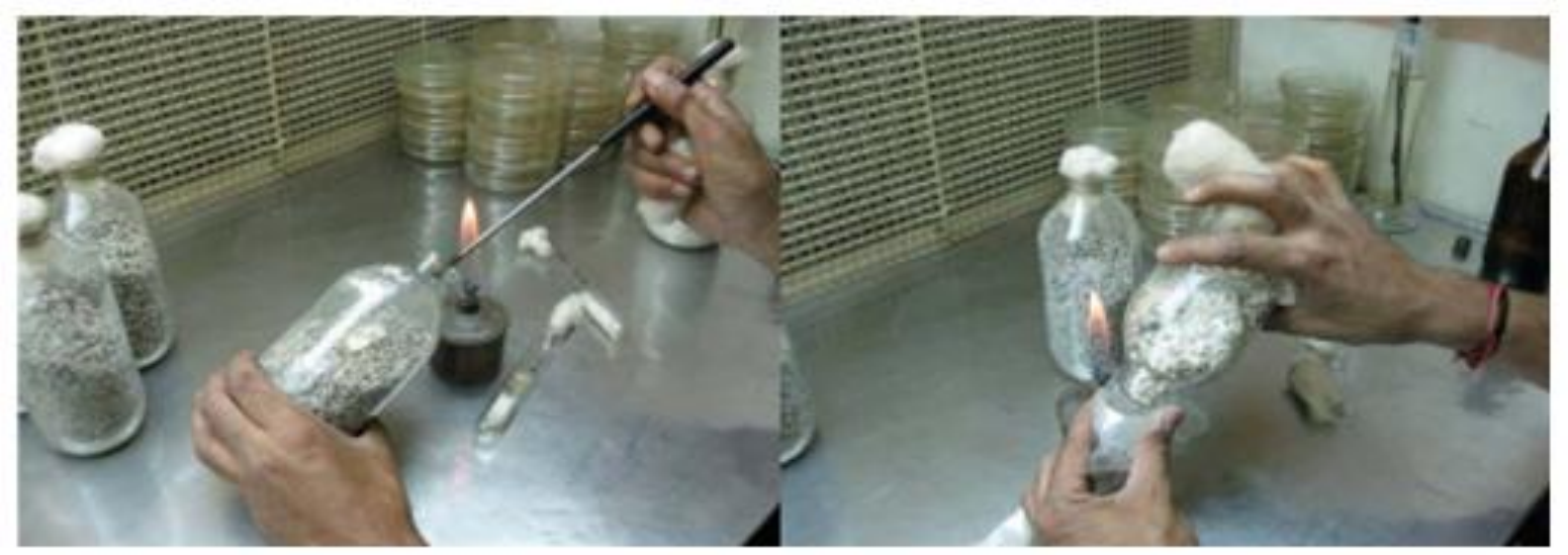

Fig.2 Wheat straw composting for button mushroom

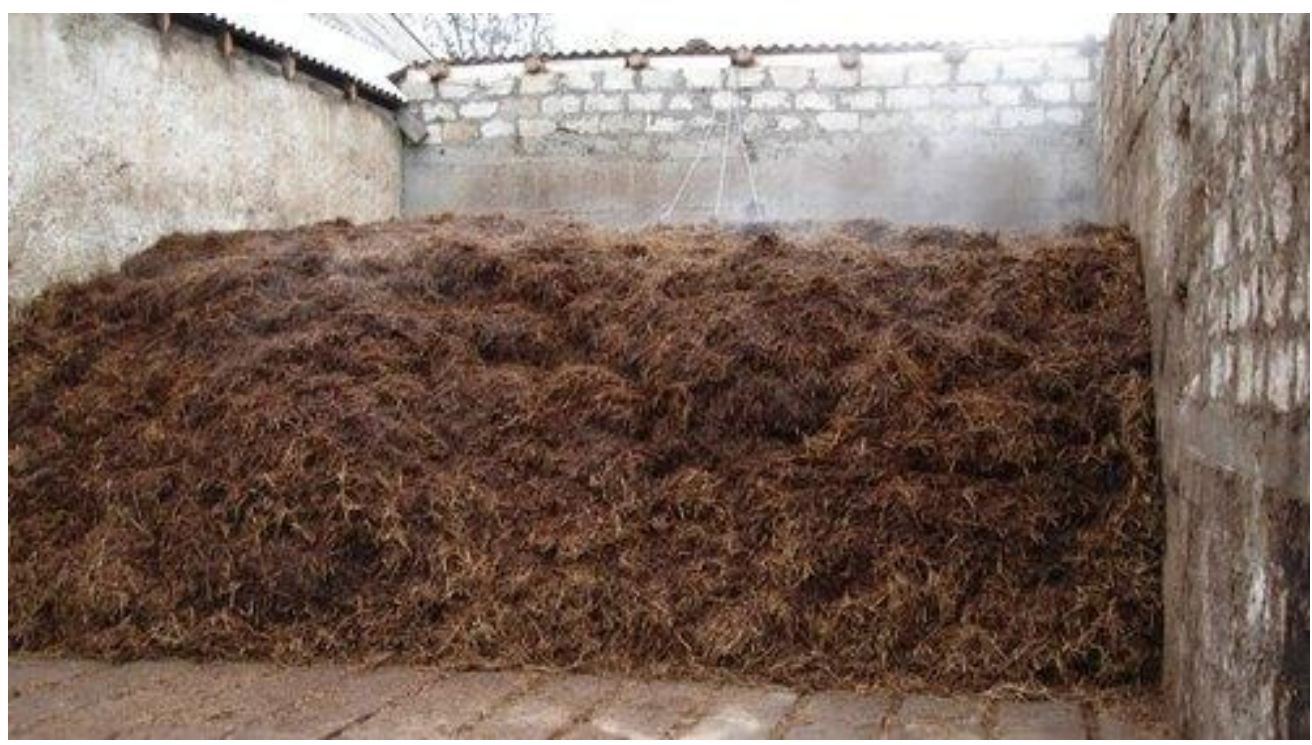


Fig.3 Filling and spawning of button mushroom
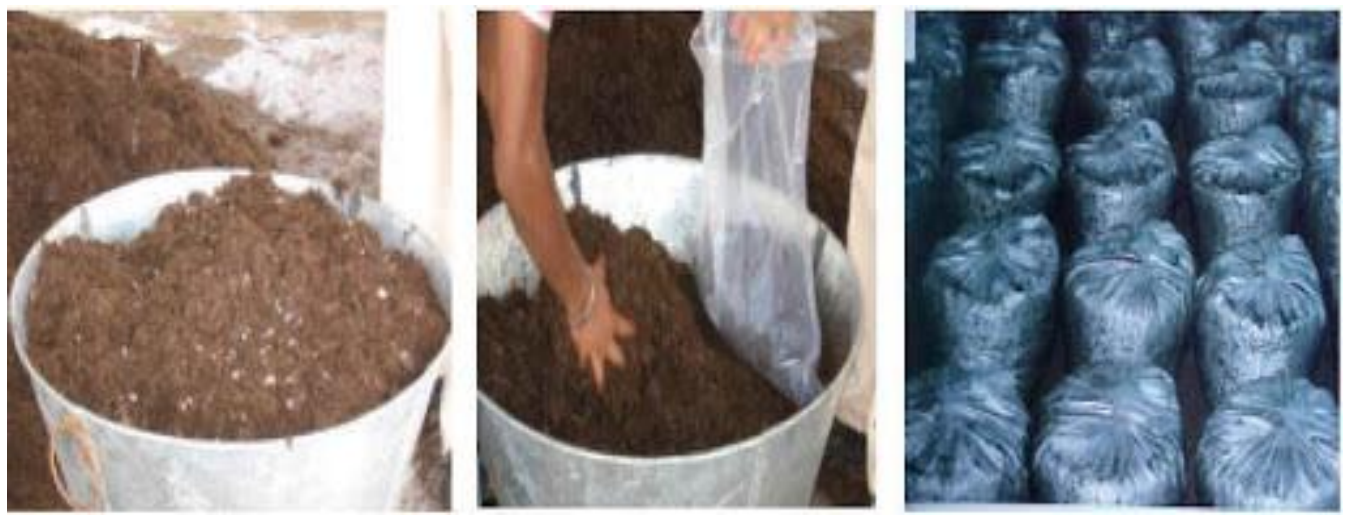

Fig.4 Process of casing for button mushroom cultivation
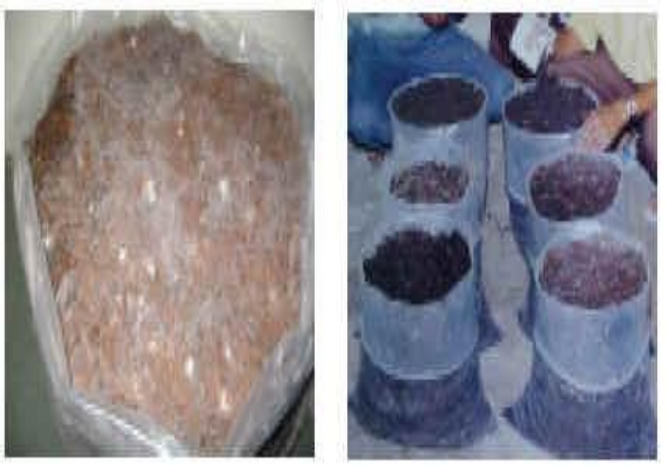

\section{Anti-inflammatory activity}

The anti-inflammatory activity of methanolic extracts of $A$. bisporus was investigated on activated macrophages and found that some edible mushrooms species have a potential anti-inflammatory capacity in-vitro (Moro et al., 2012).

\section{Enhances maturation of bone marrow derived dendritic cells}

In a study reported by Rene et al., delineated that supplementation with $A$. bisporus on the maturation of bone marrow-derived dendritic cell (BMDC)of C57BL mice and found that dose-dependently increased expression of maturation markers CD40, CD80, CD86 and major histocompatibility complex-II (Ren et al., 2008).
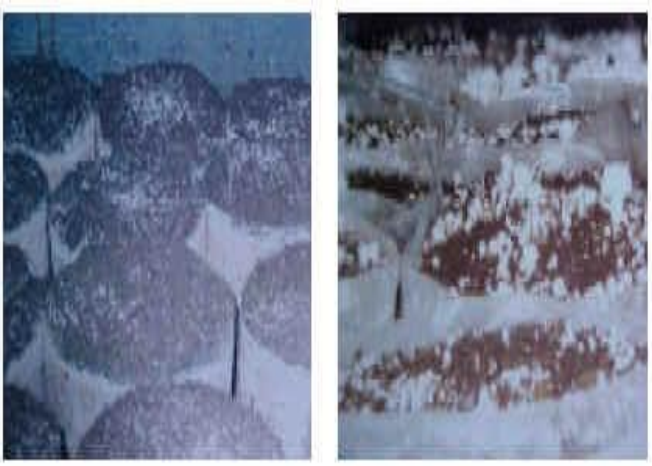

As a source of antibiotics and in cosmetics industry

A. bisporus contain a group of benzoquinone which belongs to antibiotics group and tyrosinase enzyme which was isolated from this species is completely resemble human tyrosinase which is very beneficial in field of cosmetics (Bozena et al., 2017).

\section{Intestinal fermentation}

Kawakami et al., reported the intestinal fermentation of $A$. bisporus in rats. It was proved by physical examination of animals by bacterial and HPLC analysis of cecal content and concluded that the mushroom powder of A. bisporushas a beneficial effect on the intestine (Kawakami et al., 2016). 


\section{Skin disorders}

This investigation was based on an effect of purified tyrosinase from A. bisporus on B16F10 melanocytes for the melanin production through blocking pigment cell machinery. Using B16F10 melanocytes showed that the stimulation of melanogenesis by purified tyrosinase is due to increased tyrosinase absorption. Cellular tyrosinase activity and melanin content in B16F10 melanocytes were increased by purified tyrosinase in a dose dependent manner. The results indicated that purified tyrosinase can be treated as a contestant for the treatment of vitiligous skin conditions (Zaidi et al., 2016).

\section{Antimicrobial activity}

The study involved isolating Erwinia spp. and Ralstonia solanacearum from infected plants followed by subjecting the isolates and commercially acquired Staphylococcus aureus, Enterococcus faecalis, Escherichia coli, Pseudomonas aeruginosa, Streptococcus pneumoniae, Proteus vulgaris, Candida albicans, Aspergillus niger, Fusarium oxysporum, Ustilago maydis, Microsporum gypseum and Malassezia furfur were successfully antagonized by extracts of $A$. bisporus mushroom(Waithaka et al., 2017).

\section{A. bisporus as nanoparticles}

Owaid et al., developed the methanolic nanoparticles of A. bisporus have various advantages to treat cancer, viral, bacterial, fungal diseases, etc... This type of the nanoparticle synthesis by edible and medicinal mushrooms are economic and suitable to apply in nanomedicine due to the huge number of fruiting bodies which are produced in the world (Owaid and Ibraheem, 2017; Esskandari et al., 2017; Majumder, 2017).The commercial mushroom production process is usually performed in buildings or tunnels under highly controlled environmental conditions. In nature, the basidiomycete $A$. bisporus has a significant impact on the carbon cycle interrestrial ecosystems as a saprotrophic decayer of leaf litter (Kabel et al., 2017). A. bisporus mushroom is a useful bio-factor for agro-waste recycling and can be grown on various composts, such as composts of wheat straw, reed plants, waste paper, oat straw, waste tea leaves and some water plants. Our review study delineated that button mushroom can possibly be cultivated under laboratory condition. This can be a means of livelihood, a source of economic empowerment for women in both urban and rural areas for small holder farmers apart from being a source of food production. A. bisporus has diverse pharmacological activities. Mainly in the pharmaceutical field, it was used for synthesis of nanoparticles with antimicrobial and anticancer activities. The huge quantities of $A$. bisporus mushroom grown are suitable for the nanomedicine field to synthesize ecofriendly nano-drugs. Furthermore, $A$. bisporus are a valuable asset for the welfare of humans since they have tremendous medicinal food, drug and mineral values.

\section{Future Perspectives}

The use of genetic engineering in mushroom industry will be determined by economic factors related to necessity and resources. Due to funding constraints, mushrooms are very much lagging behind other crops in terms of advancement in molecular biotechnology. Public acceptance of genetically modified foods and greater consumption of mushrooms can increase research efforts. Traits controlled by single genes such as viral, insect resistance, resistance to fungal, bacterial pathogens and pesticides can be targeted first since they are simpler to tackle.

With mapping of the mushroom genome and understanding of the functional genomics in 
mushrooms, complex traits such as yield, size, colour, shelf-life, and physical stress which are controlled by more than one gene can be undertaken in the future. Mushrooms can also be utilized as bioreactors in industry for the synthesis of proteins and pharmaceutical compounds. A higher biomass of mushrooms can be produced on low-cost waste materials in a secure containment facility with the option of automation and mechanical harvesting. The proteins manufactured in mushrooms will also have higher specific biological activities in humans than those produced from plants. The production of new mushroom cultivars with novel and improved traits will provide the industry with options for solving food problems and increase the production efficiency. Improvement of tools available to the breeder, decoding mushroom genome and commercial pressure facing the industry can propel efforts for new strain development in the future.

\section{References}

Alkaisi M R, Hasan A A, Aljuboori A W. 2016. Evaluation of production efficiency for some cultivated mushroom strains Agaricus bisporus which was renovated mother culture in multiple methods. Iraqi Journal of Science57(1B).

Andersson H C, Gry J. 2004. Phenyl Hydrazines in the Cultivated Mushroom Agaricus bisporus Occurrence, Biological Properties, Risk Assessment and Recommendations. Nordic Council of Ministers, Copenhagen. Tema Nord 558, Ekspressen Tryk \& Kopicenter1-123.

Andrade M C, Jesus J P, Vieira F R, Viana S R, Spoto M H, Minhoni M T. 2013. Dynamics of the chemical composition and productivity of composts for the cultivation of Agaricus bisporus strains. Brazilian Journal of Microbiology44(4):1139-46.

Andrade M C, Zied D C, Minhoni M T, Kopytowski Filho J. 2008. Yield of four
Agaricus bisporus strains in three compost formulations and chemical composition analyses of the mushrooms. Brazilian Journal of Microbiology39(3):593-8.

Atkins F C. 1974. Guide to Mushroom Growing. London: Faber and Faber 122.

Bacci L. 2012. Livi Bacci M. A concise history of world population. 5th ed. Malden (MA): Wiley-Blackwell: p.50.

Bahl N. 1983. Medicinal Value of Edible Fungi. In: Proceeding of the International Conference on Science and Cultivation Technology of Edible Fungi. Indian Mushroom Science II p. 203-9.

Baysal E, Yigitbasi O N, Colak M, Toker H, Simsek H, Yilmaz F. 2007. Cultivation of Agaricus bisporus on some compost formulas and locally available casing materials. part 1: wheat straw-based compost formulas and locally available casing materials. Afr. J. Biotechnol6(1):2225-2230.

Beyer D M. 2003. Basic procedures for Agaricus mushroom growing. Pennsylvania State University, College of Agricultural Sciences, Cooperative Extension.

Bonnen A M, Anton L H, Orth A B. 1994. Lignin-degrading enzymes of the commercial button mushroom, Agaricus bisporus. Applied and Environmental Microbiology60(3):960-5.

Bozena M, Katarzyna K, Jacek R, Agata G, Opoka W. 2017. Composition and biological properties of Agaricus bisporus fruiting bodies - A review. Pol J Food Nutr Sci67:173-81.

Çaglarırmak N. 2009. Determination of nutrients and volatile constituents of Agaricus bisporus (brown) at different stages. Journal of the Science of Food and Agriculture89(4):634-8.

Callac P, Imbernon M, Guinberteau J, Pirobe L, Granit S, Olivier J M, Theochari I. 2000. Discovery of a wild Mediterranean population of Agaricus bisporus, and its usefulness for breeding work. Mushroom Science 15:245-52. 
Carluccio A. 2003. Complete Mushroom Book: The Quiet Hunt. Quadrille21-2.

Chen S, Oh S R, Phung S, Hur G, Ye J J, Kwok S L, Shrode G E, Belury M, Adams L S, Williams D. 2006. Anti-aromatase activity of phytochemicals in white button mushrooms (Agaricus bisporus). Cancer research66(24):12026-34.

Colak M, Baysal E, Simsek H, Toker H, Yilmaz F. 2007. Cultivation of Agaricus bisporus on wheat straw and waste tea leaves based composts and locally available casing materials part 3: dry matter, protein and carbohydrate contents of Agaricus bisporus. Afr. J. Biotechnol6(24):28552859.

Dastager S G. 2009. Aroma compounds. In: Nigam $P$ S, Pandey A, editors. Biotechnology for Agro-Industrial Residues Utilization. Kerala, India: Springer105-27.

Elliott T J, Langton F A. 1981. Strain improvement in the cultivated mushroom Agaricus bisporus. Euphytica 30(1):17582.

Eskandari N M, Jafarizadeh M H, Rahbar S J. 2017. Hydrothermal green synthesis of gold nanoparticles using mushroom (Agaricus bisporus) extract: Physicochemical characteristics and antifungal activity studies. Green Process Synth 7:38-47.

Fan L, Pan H, Soccol A T, Pandey A, Soccol CR. 2006. Advances in Mushroom Research in the Last Decade. Food Technology \& Biotechnology44(3):303311.

Flores C, Vidal C, Trejo- Hernández M R, Galindo E, Serrano- Carreón L. 2009. Selection of Trichoderma strains capable of increasing laccase production by Pleurotus ostreatus and Agaricus bisporus in dual cultures. Journal of applied microbiology106(1):249-57.

Fritsche G. 1983. Breeding Agaricus bisporus at the Mushroom Experimental Station, Horst. Mushroom Journal122:49-53.

Gonaus C, Kittl R, Sygmund C, Haltrich D, Peterbauer C. 2016. Transcription analysis of pyranose dehydrogenase from the basidiomycete Agaricus bisporus and characterization of the recombinantly expressed enzyme. Protein Expr Purif 119:36-44.

Hawksworth D L. 1991. The fungal dimension of biodiversity: magnitude, significance, and conservation. Mycological research 95(6):641-55.

Horisawa S, Tamai Y, Terazawa M. 2006. Mushroom Cultivation Using Compost Produced in the Garbage Automatic Decompose-extinguisher (GADE). Eurasian Journal of Forest Research9(2):61-7.

Hou H, Zhou J, Wang J, Du C, Yan B. 2004. Enhancement of laccase production by Pleurotus ostreatus and its use for the decolorization of anthraquinone dye. Process Biochemistry39(11):1415-9.

Jeong S C, Jeong Y T, Yang B K, Islam R, Koyyalamudi S R, Pang G, Cho K Y, Song CH. 2010. White button mushroom (Agaricus bisporus) lowers blood glucose and cholesterol levels in diabetic and hypercholesterolemic rats. Nutrition research30(1):49-56.

Jeong S C, Koyyalamudi S R, Jeong Y T, Song C H, Pang G. 2012. Macrophage immunomodulating and antitumor activities of polysaccharides isolated from Agaricus bisporus white button mushrooms. J Med Food 15:58-65.

Kabel M A, Jurak E, Mäkelä M R, de Vries R P. 2017. Occurrence and function of enzymes for lignocellulose degradation in commercial Agaricus bisporus cultivation. Appl Microbiol Biotechnol 101:4363-9.

Kalac P. 2009. Chemical composition and nutritional value of European species of wild growing mushrooms: A review. Food chemistry113(1):9-16.

Kaur A P, Rampal V K. 2017. Assessment of Casing Mixtures on Yield Potential and Quality of Button Mushroom (Agaricus Bisporus)-On Farm Trial. International Journal of Current Microbiology and Applied Sciences 6(2):430-6. 
Kawakami S, Araki T, Ohba K, Sasaki K, Kamada T, Shimada K. 2016. Comparison of the effect of two types of whole mushroom (Agaricus bisporus) powders on intestinal fermentation in rats. Biosci Biotechnol Biochem80:2001-6.

Kerrigan R W. 1995. Global genetic resources for Agaricus breeding and cultivation. Can J Bot73:973-9.

King T A. 1993. Mushrooms, the ultimate health food but little research in U. S. to prove it. Mushroom News 41:29-46.

Li A M, Horgen P A. 1993. Attempts to develop a transformation system in Agaricus bisporus, utilizing particle bombardment and several other novel approaches. Cultivated Mushroom Research (CMR) Newsletter (United Kingdom)1:11-16.

Li G, Li R, Liu Q, Wang Q, Chen M, Li B. 2006. A highly efficient polyethylene glycol-mediated transformation method for mushrooms. FEMS microbiology letters256(2):203-8.

Maheshwari S. 2013. A Guide for White Button Mushroom (Agaricus bisporus) Production. Open Access Scientific Reports2(3):2-3.

Majumder P. 2017. Nanoparticle assisted herbal synergism an effective therapeutic approach for the targeted treatment of breast cancer: A novel prospective. Glob J Nanomed2:555-95.

Miles P G, Chang S T. 2004. Mushrooms: cultivation, nutritional value, medicinal effect, and environmental impact. CRC press.

Misharina T A, Muhutdinova S M, Zharikova G G, Terenina M B, Krikunova N I, Medvedeva IB. 2010. Formation of flavor of dry champignons (Agaricus bisporus L.). Applied biochemistry and microbiology46(1):108-13.

Moro C, Palacios I, Lozano M. 2012. Antiinflammatory activity of methanolic extracts from edible mushrooms in LPS activated RAW 264.7 macrophages. Food Chem130:350-5.

Muslat M M, Al-Assaffii I A A, Owaid M. N.
2014. Agaricus bisporus product development by using local substrate with bio-amendment. Int $\mathbf{J}$ Enviro Global Climate2(4): 176-188.

Muslat M M, Al-Assaffii I A, Alheeti M N. 2011. Use efficiency of reed residues Phragmites australis with amendment by Streptomyces o3 to prepared compost for Agaricus bisporus production and influence of spraying Glycyrrhiza $S p$. extracts. Research Journal of Aleppo University. Agricultural Science Series93:149-68.

Netam R S, Yadav S C, Mukherjee S C, Kumari P. 2018. Cultivation of button mushroom (Agaricus bisporus) under controlled condition: An initiative in Bastar Plateau of Chhattisgarh. International Journal of Current Microbiology and Applied Sciences7(10):782-7.

Owaid M N, Ibraheem I J. 2017. Mycosynthesis of nanoparticles using edible and medicinal mushrooms. European Journal of Nanomedicine9(1):5-23.

Owaid M N. 2009. Biotechnology for local compost preparation used to produce mushroom Agaricus bisporus (Doctoral dissertation, M. Sc. thesis. Biology Dept., College of Science, University of Anbar, Iraq) 129

Peker H, Baysal E, Yigitbasi O N, Simsek H, Colak M, Toker H. 2007. Cultivation of Agaricus bisporus on wheat straw and waste tea leaves-based compost formulas using wheat chaff as activator material. African Journal of Biotechnology6(4).

Prasad S, Rathore H, Sharma S. 2015. Medicinal mushrooms as a source of novel functional food. IJFS 4:221-5.

Reddy M T, Reddy K A, Reddy K A, Reddi E U, Reddi B. 2013. A study on the production of Agaricus bisporus mushrooms using Eichhornia crassipes (Mart. Solms) - a troublesome exotic aquatic weed of Kolleru lake. IJSN4(1):100-3.

Rehman M K, Ali M A, Hussain A, Khan W A, Khan A M. 2016. Effect of different 
casing materials on the production of button mushroom (Agaricus bisporus L.). Journal of Environmental \& Agricultural Science 7:55-61.

Ren Z, Guo Z, Meydani S N, Wu D. 2008. White button mushroom enhances maturation of bone marrow-derived dendritic cells and their antigen presenting function in mice. J Nutr138:544-50.

Sadiq S, Bhatti N H, Hanif M A. 2008. Studies on chemical composition and nutritive evaluation of wild edible mushrooms. JICS27:151-4.

Sassoon J, Horer S, Stoop J M H, Mooibroek H, Baumann U. 2001. Crystallization and preliminary crystallographic analysis of mannitol dehydrogenase (MtDH) from the common mushroom Agaricus bisporus. Acta Crystall57:711-713.

Sharma V P, Annepu S K, Gautam Y, Singh M, Kamal S. 2017. Status of mushroom production in India. Mushroom research 26(2):111-20.

Simsek H, Baysal E, Colak M, Toker H, Yilmaz F. 2008. Yield response of mushroom (Agaricus bisporus) on wheat straw and waste tea leaves-based composts using supplements of some locally available peats and their mixture with some secondary casing materials. African Journal of Biotechnology7(2).

Singh M P, Kaur S, Sodhi H S. 2017. Evaluation of Agaricus bisporus Lange (Sing.) Strains in the Plains of Punjab, India. International Journal of Current Microbiology and Applied Sciences 6(12):3417-25.

Stoop J M, Mooibroek H. 1998. Cloning and characterization of NADP-mannitol dehydrogenase cDNA from the button mushroom, Agaricus bisporus, and its expression in response to $\mathrm{NaCl}$ stress. Applied and Environmental Microbiology64(12):4689-96.

van de Rhee M D, Mendes O, Werten M W, Huizing H J, Mooibroek H. 1996b. Highly efficient homologous integration via tandem exo- $\beta$-1, 3-glucanase genes in the common mushroom, Agaricus bisporus. Current genetics30(2):166-73.

Van De Rhee MD, Graca PM, Huizing HJ, Mooibroek H. 1996a. Transformation of the cultivated mushroom, Agaricus bisporus, to hygromycin $\mathrm{B}$ resistance. Molecular and General Genetics MGG250(3):252-8.

Varo P, Lahelman O, Nuurtamo M, Saari E, Koivistoinen P. 1980. Mineral element composition of finish food. VII postal, vegetables, fruits, berries, nuts and mushrooms. Acta Agric 22:107-13.

Waithaka P N, Gathuru E M, Githaiga BM. 2017. Antimicrobial activity of mushroom (Agaricus Bisporus) and fungal (Trametes Gibbosa) extracts from mushrooms and fungi of Egerton main campus, Njoro Kenya. J Biomedical Sci6:3.

Weblink1:http://www.healthblog247.com/some benefits of Agaricus bisporus extract/. [Last assessed on March 29, 2021]

Zaidi K U, Ali S A, Ali A S. 2016. Effect of purified mushroom tyrosinase on melanin content and melanogenic protein expression. Biotechnol Res Int 2016:9706214.

Zhang Y, Molina F I. 1995. Strain typing of Lentinula edodes by random amplified polymorphic DNA assay. FEMS microbiology letters. 131(1):17-20.

\section{How to cite this article:}

Keshamma, E., M. S. Krishnaprasad, B. T. Sridhar, T. J. Nalini, R. Geethanjali, K. N. Shivakumara and Roy, U. B. 2021. A Review on Cultivation and Pharmacological Potential of White Button Mushroom (Agaricus bisporus). Int.J.Curr.Microbiol.App.Sci. 10(05): 243-257. doi: https://doi.org/10.20546/ijcmas.2021.1005.032 